УДК 82.09

ББК $83(2 \mathrm{Poc}=$ Рус $)+83$

$+83.3(4$ Вел $) 5 \mathrm{I}$
К ОПИСАНИЮ «ФИЛОЛОГИЧЕСКОГО ПЕРЕВОДА» В 1930-Е ГГ.:

А.А. ФРАНКОВСКИЙ - ПЕРЕВОДЧИК

АНГЛИЙСКОГО РОМАНА ХVIII В.

(C) 2017 г. М.Э. Маликова

Институт русской литературы

(Пушкинский Дом) Российской академии наук, Санкт-Петербург, Россия

Дата поступления статьи: г2 апреля 2017 г.

Дата публикации: 25 сентября 2017 г.

DOI: IO.22455/250O-4247-20I7-2-3-IO-45

Аннотация: В первой части статьи описывается явление «филологического перевода» в советской культуре г930-х гг. и, в частности, переводы А.А. Франковским английского романа XVIII в. Несмотря на то что в советской культуре с ее доминирующим марксистским дискурсом «идеалистические» философско-эстетические основания филологического перевода не могли быть описаны ни в рецензиях критиков, ни в переводческих паратекстах, они были хорошо известны переводчикам - выходцам из университетской философско-филологической среды, к которым принадлежал и Франковский, и были представлены в эти годы в нескольких важных историко-теоретических работах о переводе университетских профессоров Ф.Д. Батюшкова, М.П. Алексеева, А.М. Финкеля. Во второй части статьи на материале сохранившихся в архиве Франковского (РО ИРЛИ. Ф. І32) черновиков демонстрируется его индивидуальная ориентация в русле филологического перевода. Отмечается установка переводчика на буквальное воссоздание по-русски английского синтаксиса и в целом конструирование интеллектуального, рационального, «европейского» прозаического русского языка. Также отмечаются разительные параллели между интересом Франковского к юмору как доминанте раннего английского романа и к передаче несобственно-прямой речи, как она была проанализирована в немецкой философско-лингвистической школе Карла Фосслера, с аналогичными интересами М.M. Бахтина этих лет, что создает актуальный культурный контекст для переводов Франковского, не замеченный современниками.

ключевые слова: филологический перевод, советская культура г930-х гг., актуальность переводов классики.

Информация об авторе: Мария Эммануиловна Маликова - кандидат филологических наук, старший научный сотрудник, Институт русской литературы (Пушкинский Дом) Российской академии наук, наб. Макарова, д. 4, І99034 г. Санкт-Петербург, Россия.

E-mail: maria.e.malikova@gmail.com 


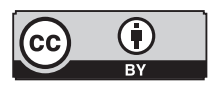

This is an open access article distributed under the Creative Commons Attribution 4.0 International (CC BY 4.O)

\section{TOWARDS THE DESCRIPTION OF} "PHILOLOGICAL TRANSLATION"

IN THE 1930s: ADRIAN A. FRANKOVSKY

AS TRANSLATOR OF THE $18^{\text {th }}$ CENTURY

ENGLISH NOVEL

(C) 20I7. M.E. Malikova

Institute of Russian Literature (Pushkin House)

of the Russian Academy of Sciences,

St. Petersburg, Russia

Received April I2, 2017

Date of publication: September 25, 2017

Abstract: The first part of the article describes the phenomenon of "philological translation" in the Soviet culture of the 1930 s and, in particular, translations of the $18^{\text {th }}$ century English novels by Adrian A. Frankovsky. Within the Soviet culture with its dominating Marxist discourse, "idealistic" philosophical-aesthetic foundations of philological translation were absent from critical reviews or translators' paratexts. However, these concepts were well familiar to translators from the university philosophical and philological habitus, to which Frankovsky also belonged, and were presented in a number of theoretical and historical works on translation authored by such university professors as Fyodor D. Batyushkov, Mikhail P. Alexeev, and Alexander M. Finkel'. Their brief overview allows to trace the origins of Frankovsky's concept of translation. The second part of the article is based on the draft materials preserved in Frankovsky's archive (Manuscript Department of Pushkin House, Fund I32). Their analysis allows to demonstrate Frankovsky's individual orientation within the field of philological translation. Frankovsky was focused on literal reproduction of the foreign syntax in the Russian language and thus endeavored to construct a more intellectual, rational, "European” Russian language. There are also striking parallels between Frankovsky's interest in humor as the dominant of the early English novel and his conveyance of indirect speech (as it was analyzed within German linguistic school of Carl Vossler) with similar interests of Mikhail M. Bakhtin at the same time. This allows us to place Frankovsky's translations within the cultural context that remained unnoticed by his contemporaries.

Keywords: philological translation, Soviet culture of the I930s, actuality of translating classics

Information about the author: Maria E. Malikova, $\mathrm{PhD}$ in Philology, Senior Researcher, Institute of Russian Literature (Pushkin House) of the Russian Academy of Sciences, Makarova embankment 4, 199034 St. Petersburg, Russia.

E-mail: maria.e.malikova@gmail.com 
Ленинградский переводчик Адриан Антонович Франковский (I888I942) известен прежде всего как создатель «русского Пруста» - выполненных им в середине г920-x - I930-х гг. переводов романов из эпопеи «В поисках за утраченным временем», отличающихся от позднейших советских переводов Н.М. Любимова тем, что в них «слышна была умная речь автора <...>. Интонация сухого, резкого, острого ума была даже усилена по сравнению с оригиналом <...>. Это был перевод во всех смыслах слова современный» [I4]. Созданный Франковским в г930-е гг. до сих пор дефинитивный «русский Стерн» - переводы «Сентиментального путешествия» и «Тристрама Шенди» - вышел позже, в неудачное время (соответственно, в І940 и І949 гг.), что помешало ему сыграть роль в «целевой культуре перевода». И едва было отмечено в целом историко-филологическое значение делавшихся Франковским на протяжении десяти лет переводов классического английского романа XVIII в., которые он неизменно сопровождал фундаментальными предисловиями и комментариями, а также специфика сконструированной переводчиком для его адекватной передачи русской дикции. Помимо Стерна, над которым Франковский начал работать в конце г934 г., им были радикально отредактированы для издательства «Academia» и в значительной степени доработаны (переведены выпущенные ранее по цензурным и эдиционным причинам эпизоды), а также снабжены примечаниями и исследовательскими преамбулами «От редактора» два старых русских перевода классики раннего английского романа - «Путешествия в некоторые отдаленные страны Лемюэля Гулливера» Дж. Свифта (г28; 2-е изд. - І930; пер. П. Кончаловского и В. Яковенко впервые опубл. в І889 г.) и «Ро- 
бинзона Крузо» Д. Дефо (г929; пер. М.А. Шишмаревой и 3.Н. Журавской впервые опубл. в 1902 г.); после чего, также в «Academia», вышли его оригинальные переводы памфлетов Свифта «Сказка бочки» и «Рассуждение о механическом действии духа» (I93I) и романа Дефо «Молль Флендерс» (1932). Перевод «Сентиментального путешествия» Стерна, а также его воспоминаний, писем и дневника Франковский сделал в 1934-I935 гг. (опубл. в г940 г.), «Тристрама Шенди» в І937-г940 гг. (опубл. в 1949 г., через семь лет после смерти переводчика). Наконец, в те же годы Франковский работал над творчеством еще одного значительного английского романиста-новатора XVIII в., Генри Филдинга - в первой половине I930-х он перевел «Историю Тома Джонса, найденыша», которая вышла в «Academia» в I935 г. (но без фундаментального историко-литературного предисловия переводчика, сохранившегося в его архиве $)$; а в 1938-г939 гг. начал перевод более раннего романа Филдинга, «Джозеф Эндрюс», из которого, вероятно, успел подготовить только «Предисловие автора». В связи со своими занятиями Филдингом, не только романистом, но и драматургом, Франковский в I940 г. совместно с Д.М. Горфинкелем по договору с издательством «Искусство» (вероятно, для серии «Библиотека мировой драматургии») перевел две английские пьесы XVIII в. - «Джон Буль, или Камин англичанина» Джорджа Колмена Младшего и «Хитрый план щеголей» Джорджа Фаркуара, - оставшиеся неоплаченными и неопубликованными.

Франковский занимался английской прозой XVIII в. в перспективе ее «филологического перевода», восходящего к традиции, прежде всего немецкой, переводов античной классики и литературного канона нового времени. Филологический перевод не равен буквальному, хотя на первый взгляд они могут казаться одним и тем же (ср.: [II]). Сущность этого тонкого отличия описана Гёте в примечании «Перевод» к «Западно-восточному дивану» (которое Вальтер Беньямин назвал одним из лучших высказываний о теории перевода [8, с. 268]): высшая, самая совершенная форма перевода, который тождественен подлиннику и при этом значительно обогащает литературные возможности родного языка «риторическими,

I РО ИРЛИ. Ф. І32. О фонде Франковского, поступившем в Пушкинский Дом сразу после смерти переводчика в блокадном Ленинграде в г942 г., см.: [23]. 
ритмическими, метрическими выгодами», в своем завершении смыкается с первоначальной формой перевода - простым прозаическим подстрочником. «По мере того, как перевод стремится отождествиться с подлинником, он все больше сближается с подстрочником и крайне облегчает понимание оригинала, так что подводит нас к основному тексту, можно даже сказать - подгоняет нас к нему <...>» [13, с. 326-329]. В «филологическом переводе», как и в буквальном, каждое слово и синтаксис по возможности точно соответствуют словам и синтаксической организации подлинника; его задача, как и задача подстрочника, - передать смысл подлинника, однако эта точность принципиально более фундаментальная в отношении исторического понимания оригинала и, как следствие, актуальная в отношении отечественной дикции.

«Филологический перевод» не сводится также и к исторической точности, достигаемой культурной археологией значений слов и реалий подлинника и находящей свое наглядное выражение как собственно в историко-литературной адекватности перевода, так и в фундаментальных комментариях и предисловиях к нему переводчика/редактора (часто столь обширных, что они могут быть опубликованы лишь частично, как примечания М.Л. Лозинского к «Божественной комедии», или требуют отдельного тома, как комментарий Г.Г. Шпета к «Посмертным запискам Пиквикского клуба»). Историческая точность составляет важную часть филологического перевода, однако ограниченный только ею он представлял бы лишь мертвый «фиктивный слепок» оригинала [I5, с. 376]. «Филологический перевод» классики есть задача по своей сути живая, актуальная для принимающей культуры, как в силу природы самого классического памятника, способного к вечному обновлению, так и благодаря позиции переводчика, обращающегося к этому произведению из той точки современности, где старые переводы стали по каким-то причинам неприемлемы и возникла потребность в новых.

Как высочайшая историко-литературная точность, так и актуальность переводов Франковского из Стерна для отечественной культуры были отмечены в немногочисленных, но существенных откликах современников, появившихся сразу по выходе в г940 г. «Сентиментального путешествия». Рецензенты единодушно формулировали то парадоксальное обстоятельство, что «в сущности до настоящего времени мы совершенно 
не знали» многократно переводившегося на русский «одного из величайших писателей Запада, могущественно влиявшего на нашу словесность (начиная от Радищева и кончая Толстым)» [43]. Об этом писал не только процитированный К.И. Чуковский, который подчеркнуто не упомянул о влиянии Стерна в интерпретации В.Б. Шкловского на русскую прозу I920-х гг., но и «невероятнейший», по словам Шкловского, Петр Сторицын (Стерн Франковского - «текстуально точный, без отсебятин, не руссифицированный, с правильно переданными интонациями и стилевыми особенностями. <..> мы можем сказать, что Стерн впервые переведен на русский язык» [33, с. I5I], подробнее см.: [9]), и Б.М. Эйхенбаум, слова которого: этот перевод «впервые раскрывает русскому читателю все намеки и тонкий смысл стерновских рассуждений и передает всю прелесть, все изящество стерновского стиля» [48, с. 3I5] - перекликаются со словами его старого товарища по ОПОЯЗу, заметившего, в связи со Стерном, что в судьбе литературного произведения могут происходить «перевороты», когда оно в восприятии нового поколения читателей «как бы пишется заново» [45, с. г99]. Однако переводы Франковского, способные, казалось бы, по своим качествам совершить новый «переворот» в русской судьбе Стерна, актуализировать его в отечественной культуре, такой роли не сыграли: дальнейшего осмысления сделанного в этих переводах, которые А.А. Елистратова позже назвала «настоящим подвигом научного исследования и художественного воссоздания оригинала» [I7, с. 656], не последовало, и на вышедший в г949 г. перевод «Тристрама Шенди» нам не удалось обнаружить ни одного печатного отклика - что вполне объясняется разгаром «борьбы с космополитизмом», «буквалистическим переводом» [I] и «схоластической шпетовщиной»².

2 Выражение из установочной речи И.А. Кашкина на заседании Секции переводчиков Союза Советских писателей ІІ марта І948 г. (РГАЛИ. Ф. 2854. Оп. І. Д. ІІ6. Л. Іо, цит. по: [56, с. 32]). У Шпета и Франковского базовые презумпции «филологического перевода» были, вероятно, общие (хотя Шпет, с его «сверхфилологической» точностью и комментариями объемом в отдельный том, конечно, представлял собой крайнюю позицию); именно Шпет в 1932 г. начал переводить Стерна для «Academia» и не возражал против передачи части работы Франковскому (см.: [9; 45, с. 269, 260]); переведенные им к 1934 г. части «Тристрама Шенди» (Кн. І, гл. І-25, Кн. ІІ, гл. І-2) хранятся в: ОР РГБ. Ф. 7І8. К. І2. Ед. хр. 5; Франковский знал о шпетовском переводе, но текста его, вероятно, не видел. 
Задача настоящей статьи - выявить некоторые основания представлений Франковского о «филологическом переводе» на материале его работы с английской прозой XVIII в. и поставить их в контекст советского филологического перевода I930-х гг. Последнее представляется необходимым потому, что Франковский сам не делал никаких мета-высказываний о переводе ни в переводческих / редакторских паратекстах, ни в критических статьях (которых не писал), ни в переписке, поэтому для понимания его представления о «задаче переводчика» важно выявление релевантного культурного контекста.

В советской истории литературы проблематика и само понятие «филологического перевода» периодически упоминались на протяжении I920-X - I930-х гг., главным образом не в более заметных и влиятельных в литературном поле критически-прескриптивных статьях и рецензиях, а в работах представителей традиционной университетской науки, а сам этот тип перевода реализовывался в продукции издававших мировую классику издательств М. и С. Сабашниковых, потом «Academia», после закрытия последнего в конце I930-х гг. - Гослитиздата (ведущие ленинградские мастера «филологического перевода» А.А. Смирнов, М.Л. Лозинский, Б.А. Кржевский, А.А. Франковский и др. были институционально связаны как с университетской наукой, так и с издательством «Academia»). Однако в советской литературе І930-х гг., эпохи расцвета «филологического перевода», не могли обсуждаться его - «идеалистические» и «буржуазные», с точки зрения оккупировавшей весь критический дискурс марксистской доксы философско-эстетические основания. То, что в конечном счете здесь не был осмыслен и усвоен тот «русский европейский» язык, который создали в те годы переводчики-филологи в до сих непревзойденных русских переводах европейской классики, как «Божественная комедия» Данте и «Гамлет» Шекспира в переводе М.Л. Лозинского, «Сентиментальное путешествие»

3 Несмотря на то что Франковский хранил полученные им письма, начиная со своего переезда в Петербург в I906 г., эпистолярии в его архиве крайне мало, а те несколько посланий, что он получил от коллег (Б.А. Грифцова, И.А. Кашкина, М.А. Кузмина, К.И. Чуковского; от последних трех по одному письму, от Грифцова - три; см. также письма Франковского Грифцову г927-І938 гг. в: РГАЛИ. Ф. 2І17. Оп. І. № 7), ценивших его переводы, носят сугубо деловой характер и написаны в уважительном, но сухом тоне. Исключение составляют несколько писем испаниста Б.А. Кржевского г9І6-г934 гг., с которым Франковского связывали близкие дружеские отношения. 
Стерна в переводе А.А. Франковского, «Дон Кихот» Сервантеса в переводе под редакцией Б.А. Кржевского и А.А. Смирнова и проч., целого ряда произведений античной и восточной литератур, связано с отсутствием в печатной советской культуре І930-х гг. адекватного критического дискурса для его описания, место которого заняли редукционистская историко-литературная периодизация и соответствующее деление писателей на «буржуазных», «реакционных», «реалистов» и проч.4, оценочное и вульгарно осовременивающее «классовое» прочтение памятников прошлого зии критиков, но и фундаментальные предисловия и комментарии самих переводчиков и редакторов, являющиеся неотъемлемой частью «филологических переводов», хотя до собственно вульгарно социологических объяснений почти не опускались, были сведены к обзору существующей литературы, главным образом иностранной, очерку истории русских переводов и культурологическому пояснению реалий. Скромный технический статус паратекстов от переводчика / редактора перевода позволял им сохранять идеологическую нейтральность, однако при условии сугубо объективного компилятивного историко-литературного характера.

Таким образом, философско-эстетические основания сделанных в I930-е гг. переводов классики и их актуальность для отечественной культуры остались невыявленными - при этом можно уверенно предположить,

4 Ср.: Пруст - «энциклопедия буржуазного паразитизма» [І2, с. I54]; Филдинг - «буржуазный моралист, вступает <...> в борьбу с Филдингом-реалистом» [16, с. 55]; «Свифт воплотил в себе весь пессимизм, всю злобу, всю безнадежность старых разбитых классов, оттеняемых капиталом и новой обуржуазившейся аристократией. С цинизмом отчаяния он изображал нового буржуазного человека <...>. Дефо стоит по другую сторону правящей аристократии. Он сын поднимающейся плебейской буржуазии - плебей, хотя еще и не демократ. <...> Из принципиального защитника своего класса он сделался агентом аристократических политиков. Его художественные произведения лишены четкой политической направленности. Он не судит, не учит - он информирует и развлекает. Своей социальной “скромностью” он типичен для буржуазной массы своего времени» [24, c. IX-X].

5 Ср.: «Современный советский читатель доскажет за автора выводы, каких он, вследствие своей исторической и классовой ограниченности, не сделал <...» [33, с. 34]; «Начиная с Теккерея, английская буржуазная критика делает не одно усилие, чтобы похоронить истинное реалистическое значение Филдинга, которое становится ей все более не по плечу. Поэтому особенно своевременно (издание «Истории Тома Джонса». - М.M.) у нас в стране, массовый читатель которой сумеет оценить по достоинству смелость, бодрость и жизнерадостность творчества великого английского романиста» [I6, с. 57]; «Робинзон - несомненно самая бодрая книга во всей буржуазной литературе. <...> Единственный наследник того, что было бодрого и здорового в Робинзоне, - строящий социализм пролетариат» $[24$, c. XVI]. 
что сами мастера «филологического перевода», вынужденно выбрав в эти годы «нишу» переводческой и редакторской деятельности, относились к задаче переводчика в первую очередь как к задаче понимания и не могли не внести в нее философские основания, поскольку все они в начале карьеры, в г9го-е - начале г920-х гг., формировались как философы, в университетской интеллектуальной среде, пропитанной неокантианскими и феноменологическими идеями. Это относится не только ко вполне очевидной в этом контексте фигуре Г.Г. Шпета, чьи радикальные переводческие и комментаторские приемы и подходы весьма вероятно вытекают из его философии слова, но и А.А. Смирнова, которого Андрей Белый, встретив в салоне Мережковских, заметил как «философа Смирнова», говорившего о Канте и имевшего собственные философские амбиции [3І, с. I7, прим. 5I]; и М.Л. Лозинского, поэта-постсимволиста, который в отношении переводческого метода придерживался более «филологического» подхода, чем филолог А.А. Смирнов [47, c. I22-I23]. Франковского знавшие его в начале г920-х гг. люди также запомнили как «ученого и философа», интересующегося современной немецкой философией [5I, с. гог] $]^{6}$ «переводчика Шпенглера» [34, с. I30]7.

6 Ранние американские исследователи творчества и биографии М.М. Бахтина К. Кларк и М. Холквист сообщают, что Франковский в начале г920-х «иногда захаживал» («was <...> occasional visitor») на бахтинский семинар в Ленинграде [55, с. Іог] - других подтверждений этому нам не удалось обнаружить, однако сама возможность близости Франковского, с его консервативными для І920-х гг. философскими интересами, к кругу Бахтина представляется вполне вероятной. Философские интересы Франковского восходят к его учебе в петербургском университете, где он был близок к профессору-неокантианцу и психологу А.И. Введенскому и позже, вероятно, входил (в 1918 г.) в Братство святой Софии Д.В. Болдырева, что позволяет предположить его знакомство с философскими текстами Болдырева (см. его вышедшую посмертно книгу «Знание и бытие» (Харбин, І935, с предисл. Н.О. Лосского)) и с его яркой религиозно-политической публицистикой петроградского периода (статьи 1915-1917 гг. в журналах «Русская мысль» и «Русская свобода»). Первый опубликованный перевод Франковского, вышедший еще в студенческие годы, - «Введение в теорию познания» немецкого философа-неокантианца Августа Мессера (г9Іо; «Einführung in die Erkenntnistheorie», I909). В І92I-I923 гг. он состоял членом и секретарем университетского Философского общества (которое возглавляли в эти годы Э.Л. Радлов и Н.О. Лосский) и участвовал в издававшемся им журнале «Мысль» (см. его очерк «Философское общество при Петроградском университете» в: Мысль. 1922. № І. С. І87-188), где опубликовал «Обзор немецкой философской литературы I9I4-I92I г.» (Там же. 1922. № 2-3); участвовал в периодическом издании Лосского и Радлова «Новые идеи в философии», где вышли его переводы статей Х. Зигварта «Основные вопросы этики» (I9I4. Сб. І4) и Р. фон Шуберт-Зольдерна «О бессознательном в сознании» (I9I4. Сб. І5).

7 Франковский был редактором выполненного коллективом авторов перевода «Заката Европы» (1923) О. Шпенглера - судя по сохранившимся в архиве переводчика 
Несмотря на то что свои представления о филологической «задаче переводчика» Франковский не эксплицировал, круг известных ему, как университетскому философу, релевантных для понимания перевода общеевропейских философско-эстетических идей вполне очевиден и был очерчен в нескольких работах по истории и теории перевода, вышедших в 1920-1930-е гг. из университетской филологической среды - Ф.Д. Батюшкова, А.М. Финкеля, М.П. Алексеева. Впервые, вероятно, в советское время филологическое понимание перевода было обозначено в двух статьях Батюшкова, добавленных в известный сборник статей Гумилева и Чуковского «Принципы перевода» (впервые: «Всемирная литература», г9г9) при его переиздании в г920 г. Несмотря на старомодный академический тон этих небольших работ, устарелость воззрений их автора на природу языка, отсутствие боевитой полемической категоричности и слабую возможность влияния, поскольку Батюшков только что умер и статьи были напечатаны в мемориальном порядке, эти тексты создают важный концептуальный противовес более известным субъективным и дидактически-прескриптивным статьям Гумилева и Чуковского и демонстрируют, что и в те годы специалист-филолог, оказавшийся перед необходимостью написать общий очерк проблемы перевода, отнюдь не чувствовал себя, в отличие от Чуковского, «одиночкой, бредущим по неведомой дороге», лишь «смутно» и «инстинктивным литературным чутьем» ощущавшим, что такое перевод [44]. Ученый имел опору в большой европейской филологической традиции, прежде всего в немецкой философской лингвистике и искусствознании - теории и практике перевода у В. фон Гумбольдта, Ф. Шлейермахера, немецких романтиков, взгляды которых, как писал в важнейшей книге по истории и теории перевода 1929 г. харьковский профессор А.М. Финкель, и сейчас «составляют основу всех рассуждений о переводе» [37, с. 62]. «Современная европейская литература, посвященная теории перевода, - как заметил в лекции, прочитанной в конце г927 г. в Саратовском университете и вышедшей в І93І г. отдельной брошюрой, снабженной обширной библиографией вопроса, другой отечественный представитель “филологического перевода”, ученый-компаративист М.П. Алексеев, - поистине необозрима», в различные исторические эпохи и часто в одну и ту же эпоху вопрос

(РО ИРЛИ. Ф. І32) текстам с редакторской правкой, он фактически заново переписал весь перевод. 
о задаче переводчика уже решался разными, зачастую находящимися в резком и явном противоречии между собою, способами [2, с. І2]. Батюшков принципиально противостоит позиции Чуковского, не называя его имени, когда говорит, что переводчика следует уподоблять не актеру (который, по Чуковскому, «преображается» в автора [4I, с. 25]), а филологу: актер в своей работе воплощения хотя и подчинен замыслу автора, но располагает разными возможностями, Отелло в исполнении разных актеров - «это все разные Отелло по канве замысла Шекспира»; переводчик же должен воспроизвести то, что дано. Актер, воплощая, имеет перед собой возможности открывать новое; переводчик, как и филолог, познает познанное» [4, с. I4-I5].

Философским горизонтом рассуждений о переводе в статьях Батюшкова служит мысль о фундаментальной невозможности перевода, о непереводимости, поэтому он утверждает противоречащую идеологии «Всемирной литературы», но принципиально важную для понимания философско-лингвистического фундамента проблемы перевода аксиому: «никакой, даже самый современный, перевод не может вполне заменить чтение художественного произведения в подлиннике» [4, с. го]. Батюшков ссылается на А.А. Потебню (писавшего, что «язык настраивает весь механизм мысли особым, так сказать, индивидуальным образом» и, следовательно, всякий перевод с одного языка на другой есть всегда «переложение своими словами», изменяющее содержание подлинника [4, с. II]; ср.: [25, с. 263-264]), который в свою очередь опирался на Гумбольдта в изложении Штейнталя. Два релевантных для практики «филологического перевода» фундаментальных подхода, следующих из этого философского основания, это - предпочтение «очуждающего» (verfremdend) перевода «доместицирующему» и соответствующая способность таких переводов обновлять национальный язык; и понимание перевода как прежде всего герменевтической процедуры, «модуса сосредоточенного понимания» [56, с. I89], акцент на природе оригинала и его автора, а не на «творческой личности» переводчика ${ }^{8}$ и не на коммуникативном аспекте перевода, т. е. фигуре современного отечественного читателя. Наиболее под-

8 С точки зрения «филологического перевода» тема «творческой личности переводчика», которая прежде всего интересует Чуковского, не является первостепенной - «индивидуальность переводчика» подчиняется автору «безусловно» [4, с. Іо] - основной вопрос: как индивидуальность автора оригинала воплощена в «стиле [его] языка» [5, с. 23]. Соответственно, задача переводчика - это задача понимания: «...вдуматься в язык писателя и выяснить себе его стиль <...» [5, c. 22]. 
робное и фундаментальное изложение философские основания взглядов на перевод получили в этот период в советской России в написанной на украинском языке книге А.М. Финкеля, профессора Харьковского университета, автора «Критического введения к Потебне» (предисловия к книге Потебни «Из лекций по теории словесности». Харьков, І930), переводчика сонетов Шекспира и одного из авторов сборника пародий «Парнас дыбом» (I925), «Теория и практика перевода» (Харьков, І929), которая, несомненно, является центральным историко-теоретическим трудом в истории советского «филологического перевода» I930-х гг. и заслуживает гораздо более подробного изложения, чем уместно в рамках настоящей статьи.

Батюшков и Финкель с их опорой на немецкую философскую традицию были современны общеевропейским поискам в теории перевода первого тридцатилетия XX в., которые в основном «восходят к немецким литературным и философским традициям, к романтизму, герменевтике и экзистенциальной феноменологии» [57, с. II]. В послевоенные годы советская теория перевода, как известно, надолго отошла от общеевропейского философского пути, приобретя характер по преимуществу идеологической критики и технического лингвистического анализа. Признаки этого вынужденного отказа теоретиков перевода г930-х гг. от философских оснований, сформировавших их интеллектуальный этос, можно различить и ранее. А.В. Федоров в книге І94I г. кается, что в своих старых работах, «не становясь в принципе на точку зрения непереводимости, все же слишком сильный упор делал на примеры несовместимости формально-языковой и художественно-смысловой передачи отдельных деталей оригинала, рассматривая их самих по себе, и из этого порой вытекали наивно-пессимистические или скептические выводы» [35, с. 4-5] и, признавая достигнутый переводчиками символистской эпохи новый уровень точности, повторяя известные слова В.Я. Брюсова из его статьи «Фиалки в тигеле» (1905) и испаниста Д.К. Петрова о том, что, учитывая заведомую невозможность, неудачу всякого перевода, способного дать лишь «неточную копию», следует, может быть, «вовсе не переводить. <...> Не лучше ли уединенному любителю поэзии взять на себя труд выучиться чужому языку, одолеть любимое произведение в подлиннике, целиком и основательно овладеть им?», замечает, что эти мысли происходят из идеалистической эстетики и недостаточной заботы об интересах читателя [35, с. І2], и противопоставляет им прин- 
ципы «оптимистического» «советского» перевода, передающего «идейное целое» подлинника. А.А. Смирнов также мотивирует отказ от идеи непереводимости тем, что в ее основании лежит «идеалистическая» точка зрения на язык [29] - тогда как его собственные литературно-эстетические воззрения, как показал Б.С. Каганович, восходили к Б. Кроче [І8], придерживавшемуся радикального взгляда на невозможность переводов [20, с. 77]. Даже А.М. Финкель в статье г939 г. апеллирует в критике непереводимости к тому несущественному обстоятельству, что сами сторонники этой «пессимистической» позиции, Гумбольдт и Потебня, дали прекрасные образцы перевода классики [38, с. 258].

И все же, несмотря на то что, как прекрасно понимали уже в г930-е гг. наиболее ориентированные на завоевание власти в поле перевода переводчики и критики, перевод является «делом большой государственной важности» [42, с. 6], в том числе и переводы классики, поскольку их периодическое «обновление» имеет остро актуальный и политический смысл «[к]аждая эпоха создает свой перевод, согласно <...> запросам своего времени» [I9, с. 2І2], власть, уделявшая в этот период преимущественное внимание переводу между русским и национальными языками народов СССР (о чем, в связи с темой перевода, в основном шла речь на Первом съезде советских писателей в I934 г.), не подверстывала еще жестко перевод классики к требованиям «социалистического реализма» и не проводила определенной идеологической линии в отношении переводчиков-филологов и «филологического перевода»9, позволяя им публично высказывать свою

9 При этом власть преследовала неофициальные объединения и студии переводчиков: в 1932 г. по делу о «контрреволюционной организации фашистских молодежных кружков и антисоветских литературных салонов» был арестован и приговорен к трехлетнему условному сроку М.Л. Лозинский. Петроградское ОГПу придумало целую схему, в центр которой был поставлен ученик Лозинского по студии перевода М.Д. Бронников, объединявший, с одной стороны, «фашистские молодежные кружки» (с такими сугубо культурными названиями, как «Бодлэровская академия», «Штроггейм клуб» и «Шекспир банджо») и «асоциальные литературные салоны»: стоящий в стороне и связанный с общим «заговором» только через фигуру Бронникова «а/с кружок Лозинского», а также «мистико-спиритуалистический кружок Наумовой В.К.», «а/с литературный салон Билибиной Т.В.» и др. (схема ОГПУ сохранилась в архиве Лозинского). В г935 г. по делу o «Немецко-фашистской организации», так называемому «Делу о Большом немецко-русском словаре», была репрессирована целая группа философов, филологов и искусствоведов круга ГАХН, много занимавшихся в г93о-е гг. переводами (М.А. Петровский, Г.Г. Шпет, А.Г. Габричевский, Б.И. Ярхо),что, в частности, повлияло на судьбу юбилейного собрания сочинений Гете. 
позицию ${ }^{\text {Iо }}$ и обсуждать разные подходы ${ }^{\text {I }}$. Последний раз «переводчики-филологи» вели почти на равных профессиональную дискуссию с «творческими» «переводчиками-поэтами», означенными сильной после Первого съезда писателей фигурой Б.Л. Пастернака и влиятельной в театральных кругах А.Д. Радловой, а также с претендовавшими на власть в литературном поле критиками К.И. Чуковским и Д.П. Святополк-Мирским, во время предвоенного обсуждения переводов для собрания сочинений Шекспира. Принцип «эквиритмии», положенный в основание нового собрания сочинений его редакторами А.А. Смирновым и Г.Г. Шпетом, маркировал приверженность определенной переводческой традиции, восходящей к переводам, в частности, из Шекспира, немецких романтиков, А. Шлегеля и Л. Тика [47, c. 728], и служил шибболетом в определении позиций спора. Этот принцип, в частности, выступал в переводе М.Л. Лозинским «Гамлета» как способ достижения «компактности словесных конструкций», «большей нагруженности понятиями каждого слова», «дисциплины словесной культуры» [40], т. е. создания более интенсивного - современного - русского языка, который, на свой лад и никак не участвуя в дискуссиях о переводе, создавал в переводах прозы и Франковский.

К переводам Франковского в высшей степени приложимо известное утверждение о том, что ту роль, какую в поэзии играет рифма и ритм, в прозе играет синтаксис. В ту эпоху Вальтер Беньямин в своей знамени-

го Так, на первом Всесоюзном совещании переводчиков в январе г936 г. наряду с сугубо политическим по своим целям, направленным на то, чтобы быть законодателем «общих принципов, обязательных для каждого нашего переводчика» [3, с. I48] пленарным докладом театрального критика И.Л. Альтмана, в собственно переводоведческом отношении крайне путаном, были безупречно профессиональные, несмотря на компромиссность, выступления А.А. Смирнова и М.Л. Лозинского, описавших основания «адекватного перевода», соединяющего передачу буквального смысла текста и «всего существенного в его словесно-звуковом оформлении, имеющего значение не только в стихах, но и в прозе» и утверждавших необходимость предварительной фундаментальной историко-литературной работы переводчика [30; 21, с. 170-189].

II Филологические переводы классики сосуществовали с переводами сокращенными (для детей и проч.) и вольными, часто одних и тех же произведений. Так, в I935 г., когда Франковский уже сделал свой перевод «Сентиментального путешествия», а Шпет перевел часть «Тристрама», в Гослитиздате вышел перевод «Сентиментального путешествия», выполненный Надеждой Вольпин - «халтурный и сумбурный. Ее стиль - не научно-художественный, а дилетантский и обывательский» [33, c. I50-I5I], а в массовой «Библиотеке Огонька» - добросовестный, но тяжелый и устаревший перевод Д.В. Аверкиева I890-х гг. в отрывках. 
той статье «Задача переводчика» (1923) обновляет идею Шлейермахера об “очуждающем” переводе, который приближает читателя переводного текста к иностранному через точный перевод, трансформирующий переводящий язык, и говорит о том, что «чистый язык» высвобождается в переводе через буквализмы, особенно в синтаксисе. Франковский еще с первых своих французских переводов, из Анри де Ренье, считает верным как можно точнее передавать своеобразие синтаксиса иностранной прозы, который «так далек от синтаксиса прозы русской» [39], принципиально расходясь в этом с показательной для противоположного направления позицией Чуковского, категорически утверждавшего, что синтаксис в переводе должен быть обязательно русский [4I, с. I5-I9], и вызывая своими новаторскими переводами Пруста резкую критику К. Локса в журнале «Печать и революция» (І927. Кн. 8): «Двухаршинные периоды, отмечающие в подлиннике сложность мысли, кажутся в русском тексте просто варварством неуча; бесконечные “который, который”, “что, что” приводят в отчаяние $<$... >.

Этому же идеалу сохранения в переводе своеобразия иностранного синтаксиса и создания большей смысловой нагруженности каждого слова Франковский следует и в своих переводах английской прозы XVIII в. Так, правя свой перевод фразы, открывающей первую главу первого тома «Тристрама Шенди»: «I wish either my father or my mother, or indeed both of them, as they were in duty both equally bound to it, had minded what they were about when they begot me <...> , Франковский движется к тому, чтобы тонкий юмор Стерна и своеобразие его словесного строя были выражены по-русски с той же языковой компактностью, что и по-английски. Первоначальный вариант перевода «уделили некоторое (исправлено на: «больше») внимания тому, что они делают» исправлен на абстрактно-интеллектуальное «поразмыслили» (ср. «minded»), в результате чего сохраняется тонкий юмористический эффект, поскольку слово «поразмыслили» относится к тому, что традиционно (но не отцом Тристрама) понимается именно как действие, а не размышление - процессу зачатия (вернее, первоначально Франковский переводит «when they begot mе» как «производили меня на свет», но потом исправляет на однословное, как в английском, «меня зачинали»): «Я бы желал, чтобы отец мой или мать, а то и оба они вместе, ведь обязанность эта лежала одинаково на них обоих, - поразмыслили 
над тем, что они делают в то время, когда они меня зачинали». Здесь мы видим стремление переводчика к словесной концентрации русской дикции, ее «англизированию». В заметке «От редактора» к переводу «Приключений Гулливера» Франковский дает характеристику стиля, аналог которому стремится создать по-русски: «...у Свифта взвешено каждое слово; живший в “золотой век” рационализма, Свифт сам был рационалистом; его рассуждения о возникновении лжи и заблуждения (в IV части) почти совпадают с рассуждениями Декарта (в четвертом Размышлении); отличительные черты слога бробдингнежцев: ясность, мужественность и гладкость, отсутствие всякой цветистости, стремление избегать нагромождения ненужных слов и разнообразия выражений, являются идеалом, которому всегда следует Свифт». Интеллектуальный, в своих основаниях философский, русский язык, который создает Франковский в своих переводах, можно назвать, воспользовавшись определением стиля игры вымышленной Прустом актрисы Берма, «умной дикцией» $[26, \text { с. 80 }]^{\text {12}}$. В том же ключе Франковский характеризует стиль Филдинга в черновой заметке к написанному им, но оставшемуся неопубликованным фундаментальному предисловию к переводу «Тома Джонса»:

Стиль Филдинга - стиль XVIII века с его рассудочностью, логической расчлененностью, периодичностью, отсутствием эмоциональной расплывчатости - переведен (А.И. Кронебергом. - M.M.) на язык гоголевской натуральной школы, в котором все эти моменты разрыхляются, смазываются, из желания избежать сухости. Между тем очень ценно передать все особенности слога Филдинга, исполненного тонкого, «интеллектуального» юмора и иронии. Конечно при этом следует отбросить всякую попытку стилизовать Филдинга под русский XVIII век; слишком велико несоответствие между тогдашней английской и русской культурой, и в слишком младенческом состоянии находился тогдашний русский «метафизический», по выражению Пушкина, язык (РО ИРЛИ. Ф. Із2).

I2 В самом переводе оригинального французского выражения «l'intelligence de la diction», приобретающего у Франковского несколько даже утрированный характер выразительного и экономного интеллектуального термина: «умная дикция» - наглядно видно отличие его манеры от аморфного бытового языка в переводе Н. Любимова: «понимание того, что хотел сказать автор». 
Франковский цитирует здесь слова Пушкина, который писал Вяземскому в I825 г.: «...русский метафизический язык находится у нас еще в диком состоянии. Дай бог ему когда-нибудь образоваться наподобие французского (ясного точного языка прозы, т. е. языка мыслей)» [28, с. г66], и хвалил друга, что тот «заступился явно за галлицизмы» [28, с. I67], - и актуализирует в советские г930-е гг. этот пафос Пушкина, размышлявшего сто лет назад о необходимости создания нового - «ясного, точного» - современного русского прозаического языка как языка «метафизического», «языка мыслей», в отечестве, где «ученость, политика и философия еще по-русски не изъяснялись; метафизического языка у нас вовсе не существует» [27, с. I4]. Пафос этот был близок Франковскому и в годы его интеллектуального формирования, когда философские антрепризы І9Іо-х - начала І920-х гг., в которых он деятельно участвовал (философское общество, философские периодические издания, издательство «Academia», созданное при университетском философском обществе и начавшее свою деятельность с издания нового собрания творений Платона), ставили своей целью синхронизировать отечественного читателя с современной философской и культурной мыслью Европы и ее языком; и в переводах Пруста, где он создал новый интеллектуальный русский язык, замешанный на философии А. Бергсона и искусствознании Г. Вёльфлина и опыте создания для них русского языкового эквивалента'ㄹ. Можно предположить, что свои переводы английской прозы XVIII в. с ее разработанной рациональной расчлененностью и интеллектуальным юмором Франковский также рассматривал как возможность обновления современного русского прозаического языка, претерпевавшего идеологическую «порчу» и примитивизацию.

\footnotetext{
I3 В начале I920-х гг. в переводе Франковского вышла новейшая работа А. Бергсона «Длительность и одновременность: (По поводу теории Эйнштейна)» (I923), а также «Я и оно» 3. Фрейда (1924); этот раннесоветский интерес к ключевым фигурам современной европейской мысли восходил к русской культуре г9Іо-х гг., когда, в частности, серия «Новые идеи в философии», в которой активно участвовал Франковский, открывалась статьей Бергсона «Философская интуиция» (I9I2. №I) и посвящала отдельный выпуск теме «Бессознательного» (в ее философском, не психоаналитическом, аспекте; 19I4. № 15). Перевод труда Г. Вёльфлина «Основные понятия теории искусств», вышедший в I930 г., Франковский сделал также в первой половине г920-х: в марте г924 г. он докладывал на заседании правления издательства «Academia» о «совершенной непригодности» предложенного ГИИИ перевода книги Вёльфлина, сделанного С.И. Чацкиной (ОР РНБ. Ф. пІ2о. № 6I. Л. 6), и уже осенью показал директору издательства А.А. Кроленко свой перевод этой книги, «который он сделал, так сказать, для себя, без заказа» (Там же. № 266. Л. 97); в архиве сохранился неопубликованный текст его предисловия к переводу.
} 
Сохранившаяся в архиве черновая рукопись начатого Франковским перевода романа Филдинга «Джозеф Эндрюс» позволяет увидеть процесс воссоздания по-русски английского синтаксиса. В самых общих чертах ход переводческой работы Франковского таков: он начинает со смыслового подстрочника, потом в процессе многослойной стилистической правки добивается, чтобы интонация перевода, без чрезмерного насилия над русским языком, воспроизводила своеобразие «рассудочного», «логического» английского синтаксиса со множеством вводных фраз, передавая их усиленной пунктуационной расчлененностью ${ }^{\mathrm{I4}}$ :

Так как рядовой английский читатель может быть иное Весьма возможно Так как может статься, что представление (рядового англичанина) о романе у рядового английского читателя может статься иное, чем нежели у автора этих томиков, и потому он, мөжет быть, ждет на рассчитывает найт развлече ние, он следовательно ждет на последующих дальнейших страницах развлечениея, которого коего там (нет) не оказывается, и даже не предполагалось, өжет быть, то не будет, пожалуй, неуместнөым предпослать несколько слов касательно этого литературного жанра, которого нас, никтө, насколько мне известно $я$ знаю я помню не прөбовал до сих пор на нашем языке никто не пробовал на нашем языке.до сих пор, насколько я знаю, на нашем языке никто не пробовал.

\section{Окончательный текст:}

Так как представление о романе у рядового английского читателя, может статься, иное, нежели у автора этих томиков, и он, следовательно, ждет развлечения, которого на дальнейших страницах не оказывается и даже не затевалось, то не будет, полагаю, неуместно предпослать несколько слов касательно литературного жанра, до сих пор, насколько я знаю, на нашем языке никем не испробованного ${ }^{15}$.

I4 Далее в цитате вписанное переводчиком над строкой выделено курсивом, зачеркнутое - соответствующим образом, скобки принадлежат Франковскому.

I5 РО ИРЛИ. Ф. г32. Ср. оригинальный текст: «As it is possible the mere English reader may have a different idea of romance from the author of these little volumes, and may consequently expect a kind of entertainment not to be found, nor which was even intended, in the following pages, it may not be improper to premise a few words concerning this kind of writing, which I do not remember to have seen hitherto attempted in our language». 
Стремление Франковского сохранять по-русски даже объем английских синтаксических оборотов наглядно видно при сравнении с этим пассажем из романа в переводе Надежды Вольпин: «соncerning this kind of writing» она переводит «о том роде словесности» [36, с. 5], а Франковский: «касательно литературного жанра» (отметим также, что здесь, как и в приведенном выше переводе обиходной фразы Пруста «l'intelligence de la diction» интеллектуальным термином «умная дикция», Франковский подвергает оригинал аналитическому современному прочтению, заменяя «this kind of writing», что действительно можно перевести, как это сделала Вольпин, довольно аморфным выражением «род словесности», четким определением «литературный жанр», поскольку именно теме нового, создаваемого Филдингом романного жанра посвящено предисловие к роману). Аналогичным образом несколько громоздкую пассивную конструкцию «which I do not remember to have seen hitherto attempted» Франковский первоначально переводит простой активной конструкцией «никто не пробовал», как это делает и Вольпин («никто <...> не пытался»), однако потом исправляет на пассивную, как в подлиннике, компенсируя синтаксическую громоздкость подлинника морфологической: «никем не испробованного».

При анализе правленых переводчиком черновиков, сохранившихся в его архиве, можно заметить также как, двигаясь к словарно точному (буквальному) переводу и далее к точному «по смыслу» (адекватному), Франковский часто возвращается в окончательном варианте к буквальной словарной точности. Так, знаменитая фраза, открывающая in medias res «Сентиментальное путешествие» Стерна: «They order, said I, this matter better in France», - относительно которой автор предоставляет читателю гадать, к чему она относится, первоначально была переведена Франковским в современном бытовом значении («order» как «to order a meal»): «Вещь эту, - сказал я, - лучше готовят во Франции». Потом исправлена на: «Во Франции, - сказал я, - это лучше устроено» - где слово «order» передано в своем основном словарном значении («I. Method, regular disposition. 2. Established process. 3. Proper state. $<\ldots>$ 5. Regularity, settled mode» и т. д. [54]). Далее этот словарно точный перевод («устроено») заменяется на «делают»: «Во Франции, - сказал я, - делают это лучше». Использованием глагола «делают» с крайне широкой сочетаемостью и семантическим полем, переводчик добивается русского смыс- 
лового эквивалента оригинального замысла Стерна, иронически оставившего читателю максимальный простор возможных интерпретаций. Однако в окончательном печатном варианте переводчик возвращается к словарно наиболее точному «устроено». Здесь мы, как кажется, видим работу «филологического перевода», как он описан в приведенной в начале нашей статьи цитате из Гете: через осмысление текста он смыкается с буквальным переводом.

Подготовительные рабочие заметки Франковского, сохранившиеся в его архиве, также указывают на направления его филологического интереса в переводе английской прозы XVIII в. Если в опубликованных предисловиях к своим переводам Франковский уделяет особенное внимание своеобразию создававшегося Дефо, Свифтом, Филдингом, Стерном романного жанра, то в подготовительных заметках его внимание смещено к другой теме, которая в паратекстах остается почти невысказанной - своеобразию английского юмора. Из забавной книжки «An Essay on the New Species of Writing founded by Mr. Fielding: With a Word or Two upon the Modern State of Criticism» (London: Printed for W. Owen, near Temple-Bar, I75I) Франковский выписывает не остроумное рассуждение ее анонимного автора об отличии новаторского, «подражающего Природе» («реалистического», говоря более поздним языком), стиля романов Филдинга от «romance», реакцией на который он явился, а «Законы», положенные Филдингом в основу романа:

I) Humour [анонимный автор книги описывает юмор Филдинга не очень внятно: «the whole humour must diffuse itself» (p. I7) - M.M. $\left.{ }^{\mathrm{I}}\right]$

2) Характеры - каждое их слово должно соответствовать лицу [«Every word they speak must be entirely consonant to the notion the author would have his readers to entertain on them. And here it may not be amiss to remark that great analogy there is between these histories and dramatic performances <...>» (p. I7)]

The style should be easy and familiar, but at the same time sprightly and entertaining... sometimes heightened to the mock-heroic, to ridicule the bombast $[<\ldots>$, which obtains so much in the romances [p. I9-20]».

I6 Здесь и далее в квадратных скобках мы приводим выпущенные Франковским фрагменты текстов, из которых он делает выписки, или цитаты из них, необходимые для лучшего понимания сделанных переводчиком для себя кратких заметок. 
Из исследования Уилбура Л. Кросса об эволюции английского романа (Cross W.L. Development of the English Novel. New York, London: McMillan, I899) Франковский также делает выписку именно о юморе Стерна: «It is a kind of humor that evokes only the gentlest emotions of pity, to be followed by the smile. It enfranchises the heart, purging it of melancholy and giving zest to the mere bagatelles of existence»; из эссе Уолтера Бейджхота «Стерн и Теккерей» (I864): «[There is even something scholar-like in his (Sterne's. - M.M.) style. It bears the indefinable traces which an exact study of words will always leave upon the use of words. $<\ldots>$ Our present novel readers do not at all care for an elaborate caricature of the scholastic learning; it is so obsolete that we do not care to have it mimicked.] Much of Tristram Shandy is a sort of antediluvian fun, in which uncouth Saurian jokes play idly in an intelligible world» [49, с. 23I-232]. Из главы о Стерне фундаментального десятитомного труда Эрнеста А. Бейкера «История английского романа» Франковский выписывает также не пассажи о пародийной романной структуре у Стерна, а о своеобразии его юмора: «Sterne’s laughter at puritanical reticence» (имеется в виду следующий пассаж: «His (Sterne’s. M.M.) favourite jests were directed at that puritanical foible, of inviolable reticence on certain subjects and everything connected with them. He loved to make the flesh creep by uttering the forbidden word, pointing an impish finger at the very thing that ought to be ignored. The exaggerated and often hypocritical reticence of the formalist was too much for his risability and he made fair game of it» [50, с. 274]), и афоризм: «what is the laughter of genius to one man is pornography to another» [50, c. 275]. Читая знаменитые лекции Уильяма Хэзлитта об английских писателях-юмористах, Франковский останавливает внимание на вступительной, «Об остроумии и юморе», в частности: «The essence of the laughable then is the incongruous, the disconnecting one idea from another, or the jostling of one feeling against another» [53, c. 4]. B книге Кэтлин М. Линч об английской комедии эпохи реставрации его привлекает изложение теории «юморов» Бена Джонсона [55, с. I5], в книге Эдмунда Госсе «Жизнь Конгрива» - определение юмора, данное этим английским драматургом XVIII в.: «[<...>] “a singular and unavoidable manner of doing or saying anything, peculiar and natural to one man only, by which his speech and actions are distinguished from those of other men”. He is inclined to deny it to women, or states, at least, that, so far as his experience goes, "if ever 
anything does appear comical or ridiculous in a woman, I think it is little more than an acquired folly". $[<\ldots>]$ only a very small selection of whimsical natures really lend themselves to dramatic development. He (Congreve) closes with a defence of English eccentricity, which is as true as it was two hundred years ago: - "There is more of humour in our English comic writers than in any other. I do not at all wonder at it, for I look upon humour to be almost of English growth; at least, it does not seem to have found such increase on any other soil. And what appears to me to be the reason of it is the great freedom, privilege, and liberty which the common people of England enjoy» [52, с. 82]. Наконец, Франковский делает пространные выписки и частью пересказывает эссе Г.К. Честертона «Юмор», представляющее собой одноименную статью из «Encyclopaedia Britannica» (І4-е изд. I929. T. XI): «A perception of the comic or incongruous of a special sort - humour is more subtle, than wit, or on the other side more vague. A deficiency of humour to search for a definition of humour. История humour влаги <...> У Бен Джонсона юмор - the ruling passion. Отсюда далее идея о преувеличении; юмор - эксцентричность. Юморист - эксцентрик, сознавший свою эксцентричность. <...> Нынче под юмором разумеют всегда сознательный юмор and generally a rather deep and delicate appreciation of the absurdities of others. Но с ним связывается, особенно в противопоставлении wit, традиция атмосферы, окружавшей старого эксцентрика. Существ[енный] элемент: сознание, что смеясь сам являешься предметом смеха. Предполагает сознание человеч[еской] слабости, тогда как wit - проявление силы человеч[еского] интеллекта. Wit орудие сатиры. Для wit оружие легко, в то время им наносимые удары сокрушительны. <...> Wit corresponds to the divine virtue of justice Humour corresponds to the human virtue of humility».

У нас нет возможности в полной мере соотнести английское стандартное, зафиксированное в новейшем издании Британской энциклопедии представление о юморе с отечественным той же эпохи, поскольку, как известно, «Литературная энциклопедия» 1929-І939 гг. до последнего тома, где была бы статья «Юмор», не дошла (а статья «Комическое» состоит из отсылки к статье «Эстетика», которая также не вышла). В советской литературе г930-х гг. социально-бытовая сатира явно преобладала над сложным интеллектуальным юмором. Тема юмора не выделена и в переводческих/редакторских паратекстах, а также в синхронических от- 
кликах на вышедшие в эти годы новейшие и заново отредактированные и откомментированные историко-филологические переводы классики европейского юмористического романа: Рабле («Гаргантюа и Пантагрюэль» / пер. В.А. Пяста под ред. и с прим. Б.А. Кржевского. Л.: Гослитиздат, г938), Боккаччо («Декамерон»/ пер. А.Н. Веселовского; вступ. статья В.Ф. Шишмарева. Л.: Academia, г927), Сервантеса («Дон Кихот» / пер. под ред. и с комм. Б.А. Кржевского и А.А. Смирнова. М.; Л.: Academia, I929, I932). В рецензиях на английские переводы Франковского, даже из Стерна, она также не является доминирующей ${ }^{17}$. Однако интерес Франковского к юмору как ключевому элементу, формировавшему жанр английского романа, имеет разительное сходство с интересом к этому же литературному аспекту М.M. Бахтина тех лет. В лекциях первой половины І920-х о современной отечественной литературе Бахтин призывает ее отказаться от «реалистического, бытового юмора Чехова» ради гоголевской линии «идеального, символического юмора, как называют его немецкие эстетики, конструктивного юмора» [6, с. 4I2] и пишет о юморе как конструктивном элементе раннего английского романа в оставшейся в рукописи книге «Слово в романе. К вопросам стилистики романа» (книга была задумана перед отъездом из Ленинграда в г930 г. и написана в Кустанайской ссылке в г930-г934 гг.). Бахтин определяет своеобразие прозаического романного языка наличием в нем внутренней разноречивости, диалогичности. Язык вообще «населен и перенаселен чужими интенциями» [7, с. 47], он состоит из разных профессиональных, социальных, поколенческих и прочих диалектов, языков. Романист «принимает разноречие и разноязычие литературного и внелитературного языка в свое произведение. На этом расслоении языка, на его разноречивости и даже разноязычии он строит свой стиль <...> [7, с. 5I]. В качестве примера разноречия, внутренней диалогичности прозаического языка как специфической особенности романного жанра Бахтин приводит английский юмористический роман Филдинга, Смоллета, Стерна, Диккенса, Теккерея, в котором «мы найдем юмористико-пародийное воспроизведе-

I7 Актуальность Стерна для отечественной литературы Сторицын и Эйхенбаум видят в сфере психологического романа - «разложении душевной жизни на противоречивые движения и страсти» [48, с. 315], умении «изобразить сложность и противоречивость мыслей, побуждений и чувств, “приливы и отливы” в настроениях, определяющих наши поступки» [33, c. I48]. 
ние почти всех слоев современного ему разговорно-письменного литературного языка. <...> Эта, обычно пародийная, стилизация жанровых, профессиональных иных слоев языка перебивается иногда прямым (обычно патетическим или сентиментально-идиллическим) авторским словом, непосредственно (без преломления) воплощающим смысловые и ценностные интенции автора. Но основою языка в юмористическом романе служит совершенно специфический модус употребления “общего языка”. $<. .>$ Автор в той или иной степени отделяет себя от этого общего языка <...>, заставляя свои интенции преломляться сквозь эту среду общего мнения (всегда поверхностного и часто лицемерного), воплощенного в языке» [7, с. 54]. У зачинателей английского юмористического романа, особенно у Стерна, эта пародийная стилизация различных слоев и жанров литературного языка, введение чужого слова в авторское, по сравнению с Диккенсом, которому Бахтин уделяет основное внимание, утрированы: «Пародийно-объектное восприятие различных разновидностей литературного языка проникает у них <...> в очень глубокие пласты самого литературно-идеологического мышления, превращаясь в пародию на логическую и экспрессивную структуру всякого идеологического <...> слова, как такового» [7, с. 6I-62]; кроме того, у «наиболее радикальных, раблезианских представителей» юмористического романа, Стерна, Сервантеса и Жан-Поля [7, с. 57], очень существенную роль в построении языка играет «литературная пародия в узком смысле»: «Литературная пародия еще более отодвигает автора от языка, еще более осложняет его отношение с литературным языком своего времени, притом на собственной территории романа. Господствующее в данную эпоху романное слово само делается объектным и становится средою преломления для новых авторских интенций. <..> Можно сказать, что важнейшие романные образцы и разновидности были созданы в процессе пародийного разрушения предшествующих романных миров» [7, с. 62-63]. Тотальную раблезианскую пародийность, черты которой можно найти у Стерна, Бахтин характеризует в духе, отличном от того, в каком выдержана его позднейшая книга о Рабле, и при этом остро актуальном в советском контексте: он отмечает пародийное отношение Рабле почти ко всем формам «идеологического», т. е. изолгавшегося, слова, словесной патетики («патетическое слово и всякое “важное слово” для него по своей природе лживы»), «дискреди- 
тирование всякой <...> “важной” серьезности <...> идеологического слова как условной и лживой, как злостно неадекватной действительности, достигает у Рабле предельной прозаической чистоты» [7, с. 65]. Фокус философского, лингвистического и идеологического, интереса Бахтина к юмору в раннем английском романе, конечно, не совпадает с содержанием историко-литературных выписок Франковского, сделанных с ясной целью понять, как английский романный и драматургический юмор той эпохи понимался его современниками и соотечественниками, однако само это совпадение преимущественного интереса к юмору в английском романе XVIII в., выделяющее Бахтина и Франковского из общего контекста, а также прописанный Бахтиным актуальный смысл интереса к юмору, пародии как разоблачению всякого «идеологического слова» создает, как представляется, значимый контекст для понимания актуального для «принимающей культуры перевода» смысла обращения Франковского в г930-е гг. к переводам Стерна и Свифта.

Не так уж важно, является ли это совпадение интересов типологическим или Франковский в самом деле «иногда захаживал» к Бахтину в Ленинграде [5I, с. Іог], или у них были общие знакомые, которые могли пересказывать Франковскому темы, обсуждавшиеся на этом неформальном семинаре. Во всяком случае, учитывая общность их философской ориентации, типологическое сходство представляется несомненным и подтверждается еще одним на первый взгляд прикладным, техническим соображением Франковского о переводе, которое он делает в заметке от 22 марта I93I г., посвященной старому переводу романа Филдинга «Приключения Тома Джонса, найденыша» А.И. Кронебергом (это подготовительная заметка к обширному предисловию переводчика к роману, оставшемуся неопубликованным и сохранившемуся в его архиве):

Язык перевода звучит для нашего времени архаически; можно опасаться даже, что некоторые места останутся непонятными для современной читающей публики. <...> Многие стилистические и синтаксические особенности подлинника в переводе пропали. В настоящее время нельзя не считаться с исследованиями английской прозы XVIII века, произведенными в последние два десятилетия преимущественно немецкими англистами. Например, функция косвенной речи и так называемой несобственной прямой 
речи в повествовательной ткани хорошо изучена в школе Фосслера. Нельзя поэтому ни ту ни другую речь механически преобразовывать в прямую, как это мы постоянно видим у переводчика. Несобственно прямая речь, в значительной степени являющаяся новшеством Филдинга, вполне свойственна русскому языку (образцы ее мы встречаем у Пушкина, у Достоевского, и других писателей), и незачем производить подобную переделку. Это все равно, как если бы обращение Мазепы к Петру (у Пушкина): «И знает бог и видит свет: он, бедный гетман, двадцать лет царю служил душою верной...» мы переделали так: «...я, бедный гетман, двадцать лет...». Это недопустимо, потому что несобственно прямая речь всегда густо окрашена авторской оценкой, у Филдинга по большей части иронией, и вкладывать эту иронию в уста самих героев значит грубо искажать перспективу. Нельзя поэтому переводить «For her part, she could not help...» «но что касается до меня, так я не могу» (стр. І2), то же на стр. І5 и т. д.

Аналогичные замечания можно высказать относительно перевода нередких у Филдинга реторических периодов и т. д.

Ровно эту цитату из «Полтавы» как «чрезвычайно характерный пример» приводит, и именно в связи с обсуждением проблемы несобственно-прямой речи в более широком контексте исследования синтаксиса и с апелляцией к школе Фосслера, В.Н. Волошинов в книге г929 г. «Марксизм и философия языка» [Iо, с. I53-I54], что связано с общим заинтересованным вниманием круга Бахтина, в отличие от тогдашнего лингвистического мейнстрима, ориентированного на Ф. де Соссюра, к философско-лингвистическому подходу «школы Фосслера» [24], в частности, к теме несобственно-прямой речи как двуголосого слова, интерференции голосов автора и героя, которая играет важную роль в бахтинской концепции диалога в вышедшей тогда же книге «Проблемы поэтики Достоевского» (I929). Разработанность синтаксических способов передачи чужой речи, в частности, несобственно-прямая речь, по Бахтину/ Волошинову, свидетельствует об аналитической работе, о развитости в национальном языке картезианского рационализма, риторики, - качеств, в русском языке исторически представленных чрезвычайно слабо [1о, с. 342-344]. Очевидно, что такое понимание несобственно-прямой речи смыкается с описанным выше пониманием Бахтиным юмора и па- 
родии в раннем английском романе как «гибридного слова» и сводится к доминантному для него интересу к внутренней диалогичности литературного слова. Акцент Франковского на адекватном русском переводе несобственно-прямой речи, т. е. создании аналитического «синтаксического шаблона» передачи чужой речи [го, с. 342-343] для русского языка, в истории которого «не было картезианского, рационалистического периода, когда разумно-самоуверенный и объективный “авторский контекст” анализировал и расчленял предметный состав чужой речи <...> [Iо, c. 342], вписывается в отмеченную нами общую тенденцию его переводов, фундированную философско-эстетическим университетским воспитанием переводчика (и, вероятно, более поздним, скорее всего опосредованным, влиянием Бахтина), создавать по-русски рефлексивную, картезианскую, интеллектуально разработанную «умную дикцию». 


\section{Список литературы}

I Азов А.Г. Поверженные буквалисты. Из истории художественного перевода в СССР в г920-г96о-е годы. М.: Высшая Школа Экономики, 2013. 21з с. Алексеев М.П. Проблема художественного перевода. Иркутск: Изд-е Иркутского ун-та, І93І. 50 с.

3 Альтман Иоганн. О художественном переводе // Литературный критик. 1936. № 5. С. $148-169$.

4 Батюшков Ф.Д. Задачи художественных переводов // Принципы художественного перевода. Статьи Ф.Д. Батюшкова, Н. Гумилева, К. Чуковского. 2-е изд., доп.

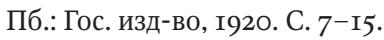

5 Батюшков Ф.Д. Язык и стиль // Принципы художественного перевода. Статьи Ф.Д. Батюшкова, Н. Гумилева, К. Чуковского. 2-е изд., доп. Пб.: Гос. изд-во, І 920. С. $16-20$. Бахтин М.M. Записи лекций по истории русской литературы // Бахтин М.M. Собр. соч.: в 7 т. М.: Русские словари, 200о. Т. 2. С. 2І3-4II. Бахтин М.М. Слово в романе // Бахтин М.М. Собр. соч.: в 7 т. М.: Языки славянских культур, 20I2. Т. 3. С. 9-339. Беньямин В. Задача переводчика. Предисловие к переводу “Tableaux Parisiens” Бодлера / пер. Е. Павлова // Бенъямин В. Учение о подобии. Медиаэстетические фрагменты. М.: РГГУ, 2012. С. 254-27і.

9 Будрин П. «Реабилитация Стерна»: Лоренс Стерн в Москве и Ленинграде I932-I94I гг. (Из истории одного издательского проекта) // Русская филология. 26. Сборник научных работ молодых филологов. Тарту, 2015. С. I7І-I82. Волошинов В.Н. Марксизм и философия языка. Основные проблемы социологического метода в науке о языке. 2-е изд. Л.: Прибой, І930. І57 с. Волчек О.Е. Литературный перевод в советской России: от автономии к идеологии вкуса // Новые русские гуманитарные исследования. 2005. № Io. URL: http:// www.nrgumis.ru/articles/I956/ (дата обращения: ог.04.2017). Гальперина Е.Л. Марсель Пруст // Литературный критик. І934. № 7-8. С. 153-I77. Гете И.В. Западно-восточный диван / изд. подг. И.С. Брагинский, А.В. Михайлов. М.: Наука, I988 (серия «Литературные памятники»). 894 с.

I4 Дашевский Г. Пропасти перевода // Коммерсант Weekend. I7 октября 2008 г. URL: http://stengazeta.net/?p=I0005373 (дата обращения: ог.04.20I7).

I5 Егунов А.Н. Гомер в русских переводах XVIII-XIX веков. М.; Л.: Наука, I964. 439 c.

I6 Елистратова А.А. Классик английского реализма [Рец. на: Филдинг Г. История Тома Джонса, найденыша / пер. А.А. Франковского. М.; Л.: Academia, I935] // Художественная литература. І935. № Іо. С. 52-6о.

Елистратова А.А. [Преамбула к примечаниям] // Стерн Л. Жизнь и мнения Тристрама Шенди, джентльмена. Сентиментальное путешествие по Франции и 
Италии / пер. с англ. М.: Худож. лит., І968. С. 655-656 («Библиотека всемирной литературы»).

I8 Каганович Б.С. А.А. Смирнов и русские переводы Шекспира г930-х годов // Laurea Lorae: Сборник памяти Ларисы Георгиевны Степановой. СПб.: НесторИстория, 201г. С. 704-727.

I9 Кашкин И.А. Мистер Пиквик и другие (Диккенс в издании «Academia») // Литературный критик. І936. № 5. С. 212-228. Кроче Б. Эстетика как наука о выражении и как общая лингвистика.

М.: Изд. М. и С. Сабашниковых, І92о. Ч. г: Теория / пер. В. [правильно: Б.] Яковенко. І7о с.

2I Багровое светило: Стихи зарубежных поэтов в переводе Михаила Лозинского / сост., автор предисл. и прим. Е. Эткинд. М.: Прогресс, 1974. 216 с.

22 Маликова М.Э. О переводчике Адриане Антоновиче Франковском по материалам его архива // Ежегодник Рукописного отдела Пушкинского дома на 2016 год. СПб.: Дмитрий Буланин, 2017. С. 37-гоо.

23 Мирский Д.П. Робинзон Крузо // Дефо Д. Робинзон Крузо. Т. I / пер. с англ. М.А. Шишмаревой и 3.Н. Журавской; под ред. А.А. Франковского. М.; Л.: Academia, I935. C. VII-XVI.

24 Попова И.Л. Книга М.М. Бахтина о Рабле в контексте идей школы Фосслера (к постановке проблемы) // Новый филологический вестник. 2005. № I. URL: http://cyberleninka.ru/article/n/kniga-m-m-bahtina-o-rable-v-kontekste-ideyshkoly-fosslera-k-postanovke-problemy (дата обращения: oг.04.20I7).

25 Потебня А.А. Эстетика и поэтика. М.: Искусство, I976. 6I4 с.

26 Пруст М. Собрание сочинений / пер. А.А. Франковского. Л.: Гос. изд-во «Худож. лит.», І936. Т. 3: В поисках за утраченным временем. Германт. 7Іо с.

27 Пушкин А.С. О предисловии г-на Лемонте к переводу басен И.А. Крылова // Пушкин А.С. Собр. соч.: в го т. М.: ГИХЛ, І962. Т. 6. С. ІІ-І5.

28 Пушкин А.С. Письмо П.А. Вяземскому, І3 июля І825 г. // Пушкин А.С. Собр. соч.: в го т. М.: ГИХЛ, І962. Т. 9. С. І66-І67.

29 Смирнов А.А. Методика литературного перевода // [Алексеев М.П., Смирнов А.А.] Перевод // Литературная энциклопедия. М.: ОГИЗ РСФСР, Советская энциклопедия, I934. T. 8. URL: http://feb-web.ru/feb/litenc/encyclop/ (дата обращения: ОI.04.20I7).

30 Смирнов А.А. О задачах и средствах художественного перевода // Литературная газета. № 2 (565). Іо января 1936. С. 2.

3I Смирнов А.А. Письма к Соне Делонэ. М.: Новое литературное обозрение, $201 \mathrm{I}$. 5 I9 c.

32 Спасский Ю. История Тома Джонса [Рец. на: Филдинг Г. История Тома Джонса, найденыша. М.; Л.: Academia, І935] // Литературное обозрение. І936. № 5 . C. $33-36$. 
Сторищын П. Реабилитированный Стерн // Литературный современник. І940. № I2. C. $148-\mathrm{I} 52$.

Тахо-Годи А.А. Жизнь и судьба: Воспоминания. М.: Молодая гвардия, 2009. 69I с. Федоров А.В. О художественном переводе. Л.: Гослитиздат, І94I. 260 с. Филдинг Генри. История приключений Джозефа Эндруса и его друга Абраама Адамса... / пер. с англ. Н. Вольпин; под ред. М.Ф. Лорие. М.: ГИХЛ, І949. 396 с. Фінкель О. Теорія й практика перекладу. Харьків, г929. Цит. по: Олександр Фінкель - забутий теоретик українського перекладознавства: Збірка вибраних праць / за ред. Л.М. Черноватого та В.І. Карабана. Вінниця: Нова книга, 2007. C. $49^{-182 .}$

38 Финкель А.M. О некоторых вопросах теории перевода // Научные записки Харьковского государственного Института иностранных языков. І939. Т. І. С. 59-82. Цит. по: Олександр Фінкель - забутий теоретик українського перекладознавства: Збірка вибраних праць / за ред. Л.М. Черноватого та В.І. Карабана. Вінниця: Нова книга, 2007. С. 227-258.

39 Франковский А.А. [Предисловие к переводу Ф.К. Сологубом романа А. де Ренье «Дважды любимая»] // Ренье А. де. Собр. соч. Л.: Academia, г926. Т. 2.

40 Чекалов И.И. Переводы «Гамлета» М. Лозинским, А. Радловой и Б. Пастернаком в оценке советской критики зо-х годов // Шекспировские чтения I990. М.: Наука, І990. С. 183-200.

Чуковский К.И. Переводы прозаические // Принципы художественного перевода. Статьи К. Чуковского и Н. Гумилева. Пб.: Всемирная литература, І9І9. С. 7-24. Чуковский К.И. Искусство перевода. М.-Л.: Academia, I936. 222 с.

43 Чуковский К. Невидимки // Литературная газета. № 63. 3 г дек. г940. С. 5 .

44 Чуковский К.И. Высокое искусство // Чуковский К.И. Собр. соч.: в 15 т. М.: Терра-Книжный клуб, 20ог. T. 3. URL: https://www.litmir.me/br/?b=I03556 (дата обращения: оІ.04.20I7).

45 Шкловский В.Б. «Евгений Онегин» (Пушкин и Стерн) // Очерки по поэтике Пушкина. Берлин: Эпоха, I923. С. I99-220. URL: http://lib.pushkinskijdom.ru/ LinkClick.aspx?fileticket=RxcFSRL_amk\%3D\&tabid=I0396 (дата обращения: OI.04.2OI7).

46 Густав Шпет: философ в культуре: документы и письма / отв. ред.-сост. Т.Г. Щедрина. М.: РОССПЭН, 2ОІ2. 675 с.

47 Густав Шпет и шекспировский круг. Письма, документы, переводы / отв. ред.-сост., предисл., коммент., археогр. работа и реконструкция Т.Г. Щедриной. М.; СПб.: Петроглиф, 2013. 760 с. («Российские Пропилеи»).

48 Эйхенбаум Б.М. [Рецензия] Стерн Л. Сентиментальное путешествие. Воспоминания. Письма. Дневник. Москва, І940 // Звезда. І940. № 8-9. С. 315-316. The Works and Life of Walter Bagehot: in Io vols. / ed. by Mrs. Russell Barrington. Vol. IV. Political and Literary Essays. Bombay, Calcutta, \& Madras: Longmans, Green \& 
Co, I9I5. URL: http://oll.libertyfund.org/titles/bagehot-the-works-and-life-of-walterbagehot-vol-4-political-literary-literary-essays (дата обращения: ог.04.20I7). Baker E.A. The History of the English Novel: in Io vols. Vol. IV. Intellectual realism: from Richardson to Sterne. London: H.F.\& G. Witherby, I936. URL: https://archive. org/stream/historyoftheengloı209ombp/historyoftheengloı209ombp_djvu.txt (дата обращения: ог.04.2017).

5I Clark Katerina, Holquist Mikhael. Mikhail Bakhtin. Cambridge, Mass.; London: Belknap Press of Harvard University Press, I984. 398 p.

52 Gosse Edmund. The Life of William Congreve. London: Walter Scott, I888. URL: https://archive.org/details/lifeofwilliamconoogossrich (дата обращения: OI.04.20I7).

53 Hazlitt William. Lectures on the English Comic Writers. New York: Wiley \& Putnam, I845. URL: https://books.google.ru/books?id=7IpFg_liEYUC\&printsec=frontcover\& $\mathrm{hl}=\mathrm{ru} \# \mathrm{v}=$ onepage \&q\&f=false (дата обращения: ог.04.20I7).

54 Johnson Samuel. A Dictionary of the English language: in 2 vols. The $6^{\text {th }}$ ed. Vol. II. London: Printed for J.F. and C. Rivington at al., I785. URL: https://archive.org/ stream/dictionaryofenglo2johnuoft\#page/n3/mode/2up (дата обращения: OI.04.20I7)

55 Lynch Kathleen $M$. The social mode of Restoration comedy. New York and London: MacMillan, I926. 242 p.

56 Steiner George. The Hermeneutic motion // The Translation Studies Reader / ed. by Lawrence Venuti. London and New York: Routledge, 2000. P. І86-г9г (впервые: Steiner George. After Babel: Aspects of language and Translation. Oxford: Oxford University Press, I975. P. 296-303).

57 Venuti Lawrence. [I900s-I930s. Introduction] // The Translation Studies Reader / ed. by Lawrence Venuti. London and New York: Routledge, 2000. P. II-I4.

58 Witt Susanna. Byron's «Don Juan» in Russia and the «Soviet school of Translation» // Translation and Interpreting Studies. 20I6. Vol. II. № I. P. 23-4I. 


\section{References}

I Azov A.G. Poverzhennye bukvalisty. Iz istorii khudozhestvennogo perevoda $v$ SSSR $v$ I920-1960-e gody [The "bukvalists" defeated. From the history of literary translation in the USSR in the I920-I960-s]. Moscow, Vysshaia Shkola Ekonomiki Publ., 2013. 213 p. (In Russ.)

Alekseev M.P. Problema khudozhestvennogo perevoda [The problem of literary translation]. Irkutsk, Izdanie Irkutskogo universiteta Publ., I93I. 5 o p. (In Russ.) Al'tman Iogann. O khudozhestvennom perevode [About literary translation]. Literaturnyi kritik, I936, no 5, pp. I48-I69. (In Russ.) Batiushkov F.D. Zadachi khudozhestvennykh perevodov [Tasks of literary translations]. Printsipy khudozhestvennogo perevoda. Stat'i F.D. Batiushkova, N. Gumileva, K. Chukovskogo, 2-e izd., dop. [Principles of literary translation. Articles by F.D. Batiushkov, N. Gumilev, K. Chukovsky, 2-nd ed., ammended]. Petersburg, Gosudarstvennoe izdatel'stvo Publ., I920, pp. 7-15. (In Russ.)

5 Batiushkov F.D. Iazyk i stil' [Language and style]. Printsipy khudozhestvennogo perevoda. Stat'i F.D. Batiushkova, N. Gumileva, K. Chukovskogo, 2-e izd., dop. [Principles of literary translation. Articles by F.D. Batiushkov, N. Gumilev, K. Chukovsky, 2-nd ed., ammended]. Petersburg, Gosudarstvennoe izdatel'stvo Publ., I920, pp. I6-20. (In Russ.)

Bakhtin M.M. Zapisi lektsii po istorii russkoi literatury [Summary of lectures on the history of Russian literature]. Bakhtin M.M. Sobr. soch.: $v 7 t$. [Collected works: in 7 vols.]. Moscow, Russkie slovari Publ., 2000, vol. 2, pp. 2I3-4II. (In Russ.)

7 Bakhtin M.M. Slovo v romane [Word in the novel]. Bakhtin M.M. Sobr. soch.: $v$ t. [Collected works: in 7 vols.]. Moscow, Iazyki slavianskikh kul'tur Publ., 20I2, vol. 3, pp. 9-339. (In Russ.)

8 Ben'iamin V. Zadacha perevodchika. Predislovie k perevodu “Tableaux Parisiens” Bodlera [The task of translator. Introduction to the translation of Baudelaire's "Tableaux Parisiens”], trans. E. Pavlova. Ben'iamin V. Uchenie o podobii. Mediaesteticheskie fragment [Treatise on similarity. Mediaesthetic fragments]. Moscow, RGGU Publ., 20I2, pp. 254-27I. (In Russ.)

9 Budrin P. «Reabilitatsiia Sterna»: Lorens Stern v Moskve i Leningrade I932I94I gg. (Iz istorii odnogo izdatel'skogo proekta) [“Rehabilitation of Sterne”: Lawrence Sterne in Moscow and Leningrad in I932-I94I (From the history of a publishing project)]. Russkaia filologiia 26. Sbornik nauchnykh rabot molodykh filologov [Russian Philology. Vol. 26. Collected works of young philologists]. Tartu, 20I5, pp. I7I-I82. (In Russ.) Voloshinov V.N. Marksizm i filosofiia iazyka. Osnovnye problemy sotsiologicheskogo metoda v nauke o iazyke, 2-e izd. [Marxism and philosophy of language. Main problems of the sociological method in the science of language, 2-nd ed.]. Leningrad, Priboi Publ., I930. I57 p. (In Russ.) 
Volchek O.E. Literaturnyi perevod v sovetskoi Rossii: ot avtonomii k ideologii vkusa [Literary translation in the Soviet Russia: from autonomy to the ideology of taste]. Novye ruskkie gumanitarnye issledovaniia, 2005, no Io. Available at: http://www.nrgumis.ru/articles/I956/ (Accessed or April 20I7). (In Russ.).

Gal'perina E.L. Marsel' Prust [Marcel Proust]. Literaturnyi kritik, I934, no 7-8, pp. I53-I77. (In Russ.)

Goethe I.-W. Zapadno-vostochnyi divan [West-East Divan], ed. I.S. Braginskii, A.V. Mikhailov. Moscow, Nauka Publ., I988. 894 p. (In Russ.)

Dashevskii G. Propasti perevoda [Abysses of translation]. Kommersant Weekend, October I7, 2008. Available at: http://stengazeta.net/?p=I0005373 (Accessed or April 20I7). (In Russ.)

Egunov A.N. Gomerv russkikh perevodakh XVIII-XIX vekov [Homer in Russian translation of the $18^{\text {th }}-2 \mathrm{O}^{\text {th }}$ centuries]. Moscow; Leningrad, Nauka Publ., I964. 439 p. (In Russ.)

Elistratova A.A. Klassik angliiskogo realizma [Classic of English realism]. Khudozhestvennaia literature, I935, no Io, pp. 52-60. (In Russ.) Elistratova A.A. [Preambula k primechaniiam] [Preface to the commentary]. Stern L. Zhizn' i mneniia Tristrama Shendi, dzhentl'mena. Sentimental'noe puteshestvie po Frantsii $i$ Italii [Sterne L. The life and opinions of Tristram Shandy, Gentleman; A sentimental journey through France and Italy], trans. Moscow, Khudozh. lit. Publ., I968, pp. 655-656. (In Russ.)

8 Kaganovich B.S. A.A. Smirnov i russkie perevody Shekspira I930-kh godov [A.A. Smirnov and Russian translations of Shakespeare of the I930s]. Laurea Lorae: Sbornik pamiati Larisy Georgievny Stepanovoi [Laurea Lorae. Collection in memory of Larissa Georgievna Stepanova]. St. Petersburg, Nestor-Istoriia Publ. 20II, pp. 704-727. (In Russ.) Kashkin I.A. Mister Pikvik i drugie (Dikkens v izdanii «Academia») [Mister Pickwick (Dickens published by “Academia”)]. Literaturnyi kritik, I936, no 5, pp. 212-228. (In Russ.)

Kroche B. Estetika kak nauka o vyrazhenii i kak obshchaia lingvistika. [Aesthetics as a study of representation and as general linguistics], trans. V. [B.] Iakovenko. Moscow, Izd. M. i S. Sabashnikovykh Publ., I920. Part I: Theory. I70 p. (In Russ.) Bagrovoe svetilo: Stikhi zarubezhnykh poetov v perevode Mikhaila Lozinskogo [Scarlet star. Poems of foreign poets translated by Mikhail Lozinsky], ed., comments and intro E. Etkind. Moscow, Progress Publ., I974. 216 p. (In Russ.) Malikova M.E. O perevodchike Adriane Antonoviche Frankovskom po materialam ego arkhiva [About translator Adrian Antonovich Frankovsky on the materials from his archive]. Ezhegodnik Rukopisnogo otdela Pushkinskogo Doma na 2or6 god [Year-book of the Pushkin House Manuscript Division]. St. Petersburg, Dmitrii Bulanin Publ., 20I7, pp. 37-IOO. (In Russ.)

Mirskii D.P. Robinzon Kruzo [Robinson Crusoe]. Defo D. Robinzon Kruzo. T. I [Defoe D. Robinson Crusoe], trans. M.A. Shishmareva i Z.N. Zhuravskaya, 
ed. A.A. Frankovsky. Moscow; Leningrad, Academia Publ., I935, pp. VII-XVI. (In Russ.)

24 Popova I.L. Kniga M.M. Bakhtina o Rable v kontekste idei shkoly Fosslera (k postanovke problemy) [M.M. Bakhtin book on Rabelais in the context of the ideas of Vossler school]. Novyi filologicheskii vestnik, 2005, no I. Available at: http://cyberleninka.ru/ article/n/kniga-m-m-bahtina-o-rable-v-kontekste-idey-shkoly-fosslera-k-postanovke-problemy (Accessed or April 20I7). (In Russ.)

25 Potebnia A.A. Estetika i poetika [Aesthetics and poetics]. Moscow, Iskusstvo Publ., I976. 6I4 p. (In Russ.)

26 Prust M. Sobranie sochinenii [Collected works], trans. A. A. Frankovskogo. Leningrad, Gosudarstvennoe izdatel'stvo "Khudozhestvennaia literature” Publ., I936. Vol. 3: $\mathrm{V}$ poiskakh za utrachennym vremenem. Germant [A la recherché de temps perdue. Le Côté de Guermantes]. 7Io p. (In Russ.)

27 Pushkin A.S. O predislovii g-na Lemonte k perevodu basen I.A. Krylova [On the introduction of Mr. Lemonte to the translation of I.A. Krylov's fables]. Pushkin A.S. Sobranie sochinenii: $v$ Io t. [Works: in Io vol.]. Moscow, GIKhL Publ., I962, vol. 6, pp. II-I5. (In Russ.)

28 Pushkin A.S. Pis'mo P.A. Viazemskomu, I3 iiulia I825 g. [A Letter to P.A. Vyazemsky, July I3, I825]. Pushkin A.S. Sobranie sochinenii: v Io t. [Works: in Io vol.]. Moscow, GIKhL Publ., I962, vol. 9, pp. I66-I67. (In Russ.)

29 Smirnov A.A. Metodika literaturnogo perevoda [Method of literary translation]. [Alekseev M.P., Smirnov A.A.] Perevod [Translation]. Literaturnaia entsiklopediia [Literary encyclopedia]. Moscow, OGIZ RSFSR, Sovetskaia entsiklopediia Publ., I934. Vol. 8. Available at: http://feb-web.ru/feb/litenc/encyclop/ (Accessed or April 20I7). (In Russ.)

30 Smirnov A.A. O zadachakh i sredstvakh khudozhestvennogo perevoda [On the tasks and means of literary translation]. Literaturnaia gazeta, Jan. IO, I936, no 2 (565), p. 2. (In Russ.)

3I Smirnov A.A. Pis'ma k Sone Delone [Letters to Sonia Delone]. Moscow, Novoe literaturnoe obozrenie, 20II. 5I9 p. (In Russ.)

32 Spasskii Iu. Istoriia Toma Dzhonsa [The story of Tom Jones]. Literaturnoe obozrenie, I936, no 5, pp. 33-36. (In Russ.)

33 Storitsyn P. Reabilitirovannyi Stern [Sterne rehabilitated]. Literaturnyi sovremennik, I940, no I2, pp. I48-I52. (In Russ.)

34 Takho-Godi A.A. Zhizn' i sud'ba: Vospominaniia [Life and destiny: Memoir]. Moscow, Molodaia gvardiia Publ., 2009. 69I p. (In Russ.)

35 Fedorov A.V. O khudozhestvennom perevode [On literary translation]. Leningrad, Goslitizdat Publ, I94I. 260 p. (In Russ.)

36 Fielding H.G. Istoriia prikliuchenii Dzhozefa Endrusa i ego druga Abraama Adamsa... [The history of the adventures of Joseph Andrews and of his friend Mr. Abraham Adams...], trans. N. Vol'pin, ed. M.F. Lorie. Moscow, GIKhL Publ., I949. 396 p. (In Russ.) 
37 Finkel' O. Teoriia i praktika perekladu [Theory and practice of translation]. Khar'kiv, 1929. Qtd in: Oleksandr Finkel' - zabutii teoretik ukraïn'kogo perekladoznavstva: Zbirka vibranikh prats' [Alexander Finkel - forgotten theorist of Ukranian translation studies. Collection of selected works], ed. L.M. Chernovatogo and V.I. Karabana. Vinnytsia, Nova kniga Publ., 2007, pp. 49-I82. (In Ukrainian)

38 Finkel' A.M. O nekotorykh voprosakh teorii perevoda [On some questions in the theory of translation]. Nauchnye zapiski Khar'kovskogo gosudarstvennogo Instituta inostrannykh iazykov [Academic notes of the Kharkov State Institute of Foreign Languages], I939, vol. I, pp. 59-82. Qtd. in: Oleksandr Finkel' - zabutii teoretik ukraïns'kogo perekladoznavstva: Zbirka vibranikh prats' [Alexander Finkel - forgotten theorist of Ukranian translation studies. Collection of selected works], ed. L.M. Chernovatogo and V.I. Karabana. Vinnytsia, Nova kniga Publ., 2007, pp. 227-258. (In Russ.)

39 Frankovskii A.A. [Predislovie k perevodu F.K. Sologubom romana A. de Ren'e "Dvazhdy liubimaia”] [Introduction to F.K. Sologub's translation of H. de Regnier's novel $L a$ Double Maitresse]. Ren'e A. de. Sobr. soch. [Collected writings]. Leningrad, Academia Publ., I926. Vol. 2. (In Russ.)

40 Chekalov I.I. Perevody "Gamleta” M. Lozinskim, A. Radlovoi i B. Pasternakom v otsenke sovetskoi kritiki 30-kh godov [Translations of "Hamlet" by M. Lozinsky, A. Radlova and B. Pasternak in evaluation of Soviet critics of the I930s]. Shekspirovskie chteniia 1990 [Shakespeare Readings I990]. Moscow, Nauka Publ., I990, pp. I83-200. (In Russ.)

4I Chukovskii K.I. Perevody prozaicheskie [Translations of prose]. Printsipy khudozhestvennogo perevoda. Stat'i K. Chukovskogo i N. Gumileva [Principles of artistic translation: essays by K. Chukovsky and N. Gumilev]. Petersburg, Vsemirnaia literature Publ., I9I9, pp. 7-24. (In Russ.)

42 Chukovskii K.I. Iskusstvo perevoda [The art of translation]. Moscow; Leningrad, Academia Publ., I936. 222 p. (In Russ.)

43 Chukovskii K. Nevidimki [The unseen]. Literaturnaia gazeta, Dec. 3I, I940, no 63, p. 5. (In Russ.)

44 Chukovskii K.I. Vysokoe iskusstvo [Sublime art]. Chukovskii K.I. Sobr. soch.: v I5t. [Collected works: in I5 vols.]. Moscow, Terra-Knizhnyi klub Publ., 200I. Vol. 3. Available at: https://www.litmir.me/br/?b=I03556 (Accessed or April 20I7). (In Russ.)

45 Shklovskii V.B. «Evgenii Onegin» (Pushkin i Stern) [“Eugene Onegine” (Pushkin and Sterne)]. Ocherki po poetike Pushkina [Essays on the poetics of Pushkin]. Berlin, Epokha Publ., I923, pp. I99-220. Available at: http://lib.pushkinskijdom.ru/LinkClick.aspx?fileticket=RxcFSRL_amk\%3D\&tabid=I0396 (Accessed I April 20I7). (In Russ.)

46 Gustav Shpet: filosof v kul'ture: dokumenty i pis'ma [Gustav Shpet: philosopher in culture: documents and letters], ed.-comp. T.G. Shchedrina. Moscow, ROSSPEN Publ., 2012. 675 p. (In Russ.). 
Gustav Shpet i shekspirovskii krug. Pis'ma, dokumenty, perevody [Gustav Shpet and the Shakespeare circle. Letters, documents, translations], ed., intro., comments, archeological reconstruction T.G. Shchedrina. Moscow, St. Petersburg, Petroglif Publ., 20I3. 760 p. (In Russ.)

48 Eikhenbaum B.M. [Retsenziia] Stern L. Sentimental'noe puteshestvie. Vospominaniia. Pis’ma. Dnevnik. Moskva, I940 [Rev. of: L. Sterne. Sentimental Journey. Memoir. Letters. Journal.], transl. by A. Frankovsky. Moscow, I940. Zvezda, I940, no 8-9, pp. 315-3I6 (In Russ.)

49 The Works and Life of Walter Bagehot: in Io vols., ed. by Mrs. Russell Barrington. Vol. IV. Political and Literary Essays. Bombay, Calcutta, \& Madras, Longmans, Green \& Co, I9I5. Available at: http://oll.libertyfund.org/titles/bagehot-the-works-and-lifeof-walter-bagehot-vol-4-political-literary-literary-essays (Accessed or April 20I7). (In English)

50 Baker E.A. The History of the English Novel: in Io vols. Vol. IV. Intellectual realism: from Richardson to Sterne. London, H.F.\& G. Witherby, I936. Available at: https://archive. org/stream/historyoftheengloı2090mbp/historyoftheengloi209ombp_djvu.txt (Accessed or April 20I7). (In English)

5I Clark Katerina, Holquist Mikhael. Mikhail Bakhtin. Cambridge, Mass., London, Belknap Press of Harvard University Press, I984. 398 p. (In English)

52 Gosse Edmund. The Life of William Congreve. London, Walter Scott, I888. Available at: https://archive.org/details/lifeofwilliamconoogossrich (Accessed or April 20I7). (In English)

53 Hazlitt William. Lectures on the English Comic Writers. New York, Wiley \& Putnam, I845. Available at: https://books.google.ru/books?id=7IpFg_liEYUC\&printsec=frontcover\&hl=ru\#v=onepage\&q\&f=false (Accessed or April 20I7). (In English)

54 Johnson Samuel. A Dictionary of the English language: in 2 vols. The $6^{\text {th }} \mathrm{ed}$. Vol. II. London, Printed for J.F. and C. Rivington at al., I785. Available at: https://archive.org/ stream/dictionaryofenglo2johnuoft\#page/n3/mode/2up (Accessed or April 20I7). (In English)

55 Lynch Kathleen M. The social mode of Restoration comedy. New York and London, MacMillan, I926. 242 p. (In English)

56 Steiner George. The Hermeneutic motion. The Translation Studies Reader, ed. by Lawrence Venuti. London and New York, Routledge, 2000, pp. I86-I9I (first published: Steiner George. After Babel: Aspects of language and Translation. Oxford, Oxford University Press, 1975, pp. 296-303). (In English)

57 Venuti Lawrence. [I900s-I930s. Introduction]. The Translation Studies Reader, ed. by Lawrence Venuti. London and New York, Routledge, 2000, pp. II-I4. (In English)

58 Witt Susanna. Byron's “Don Juan” in Russia and the "Soviet school of Translation”. Translation and Interpreting Studies, 20I6, vol. II, no I, pp. 23-4I. (In English) 